\title{
LA HUMILDE SABIDURÍA
}

\begin{abstract}
Alfonso GARCÍA
\end{abstract}
$\mathrm{D}$ icen no pocos que la literatura ha caído en desgracia. Aunque no estoy de acuerdo con la percepción, a pesar de ciertos flecos que invitan a replanteamientos y reflexiones, recurro con frecuencia a la historia, que, en todo caso, silenciosa, no se puede borrar, aunque se olvide. En su recorrido hay personas que desmienten categóricamente el principio del olvido por su esfuerzo en la lucha contra tales molinos de viento. Tal es el caso de José Enrique Martínez, el estudioso que ha puesto voz especialmente a la poesía española en general, a la leonesa en particular durante prácticamente el último medio siglo.

He tenido la suerte de poder seguir de cerca la trayectoria de José Enrique. Nos acercó la literatura y la literatura nos hizo amigos. Una suerte y un motivo mucho más que suficiente para amarla. Hay una especie de compensación de las reglas de la propia vida que la convierten en fructífera y saludable, simplemente porque trasciende la realidad aparentemente rutinaria para convertirla, sin gestos extraordinarios ni grandilocuencias, en un lazo que genera complicidades y miradas que buscan la misma dirección. Desde que éramos jóvenes, y cuánta lluvia ha caído desde entonces.

La literatura nos unió y en torno a ella compartimos múltiples proyectos. Tres décadas preparando prácticamente a diario la cita semanal del Filandón del Diario de León. Discreto siempre, curioso por antonomasia - ¿no es la curiosidad otro de los fundamentos de la sabiduría?_- capaz en todo momento de abrir ventanas de frescura y novedades a veces ni siquiera intuidas, dispuesto con la generosidad de quien se implica en una labor que exige complicidad permanente, José Enrique siempre hizo fácil todo. Siempre la sonrisa de la humildad como respuesta, la humildad de la sabiduría, llena, por otra parte, de convicciones y seguridades. Siempre he creído que humildad y sabiduría son dos conceptos inseparables que, en casos como el que nos ocupa, se convierte en paradigma. Desde el ámbito del suplemento y del periódico que lo sustenta surgieron y se consolidaron otras iniciativas en que, además, no puedo ni quiero obviar la labor, también sustantiva y fundamental, entre otros, de Nicolás Miñambres. Se sucedieron varios congresos internacionales sobre literatura leonesa actual, la publicación de los libros Relatos breves (1986-1999), Diez nuevas voces de la poesía leonesa, El Siglo de Oro de las Letras Leonesas, entendido por tal la literatura escrita por leoneses en los últimos tiempos. Y sobre todo, al menos para quien esto escribe, los cincuenta y dos títulos - uno por semana, durante un año- de la 'Biblioteca Leonesa de Escritores', que llevó más de medio millón de libros a 
los hogares leoneses. En todo este entramado de largo recorrido e indudable proyección es fundamental la aportación, el criterio y el mapa global que tan perfectamente tiene dibujado, como consecuencia de un estudio profundo y continuado basado en la finura del análisis, nuestro querido protagonista. La realidad queda ahí como testimonio de un tiempo, una época y unos frutos de notable alcance, constatados y registrados como tales en su momento. Admira en este proceso, entre otras cosas, la capacidad del estudioso y catedrático universitario por divulgar, acercar y provocar el amor hacia la literatura desde las páginas de un periódico. Su labor como investigador, de sobra conocida, queda ahora fuera de este foco. Necesita un estudio riguroso que ha de llegar desde otros ámbitos.

La vinculación de José Enrique Martínez a la literatura en general, a la poesía de forma más concreta, ha sido hasta el momento larga, constante y fructífera. Estoy seguro de que lo seguirá siendo, en beneficio de todos. Y lo ha sido por la intensidad y la capacidad de trabajo como sustento de su ejemplar trayectoria, por los análisis abiertos y por la facilidad que ha tenido a la hora de manejar con soltura diversos registros, otro de los síntomas inequívocos del verdadero conocimiento. Y es que en el contraste uno tiene mayor capacidad de acercarse a la misma realidad. Un verdadero don. Así y todo, me quedo personalmente con la añadidura del hombre dialogante, abierto y amigo. Ha sido una suerte extraordinaria haberme encontrado con él. La vida tiene estas recompensas. 